\title{
Otospondylomegaepiphyseal dysplasia
}

INSERM

\section{Source}

INSERM. (1999). Orphanet: an online rare disease and orphan drug data base.

Otospondylomegaepiphyseal dysplasia. ORPHA:1427

Otospondylomegaepiphyseal dysplasia (OSMED) is an inborn error of cartilage collagen formation characterized by sensorineural hearing loss, enlarged epiphyses, skeletal dysplasia with disproportionately short limbs, vertebral body anomalies and a characteristic facies. 